\title{
Implementation of lean manufacturing to enhance the efficiency of acrylic resins production process
}

Sahrupi, Gerry Anugrah Dwiputra, Uswatun Chasanah

Department of Industrial Engineering, Universitas Serang Raya, Jl. Raya Cilegon No.Km. 5, Banten 42162, Indonesia

\section{ARTICLE INFORMATION \\ Article history: \\ Received: June 25, 2019 \\ Revised: June 21, 2020 \\ Accepted: July 10, 2020}

Keywords:

Acrylic resins

Lead time

Lean manufacturing

Waste

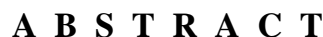

High lead time processing of acrylic resins leads to the production of products to consumer undergoes and high-production costs. This study aims to reduce lead time by analyzing various activities that have value added, non value added, and necessary non value added. The research is conducted using lean manufacturing approaches on acrylic resin production processes. The analysis shows that the activity of delay and transportation is a contributor of waste that occurs in the production process of acrylic resins. Improvements by minimizing both activities in the are thining tank, reactor, and monomer tank can increase the efficiency of the production process. The improvement results show a decrease in lead time from 1298 minutes to 1075 minutes. This study demonstrates that lean manufacturing can improve the time process efficiency of $17.18 \%$, which means the output ratio will increase by around $17.18 \%$ in a process.

\section{INTRODUCTION}

The growth of coating companies in Indonesia is increasing. This development triggers competition among paint producers and will also impact on supplier companies. The success of the manufacturing industry is related to the company's ability to face market competition. Factors that play a role in maintaining market competition include the use of cost-effectively and efficiently.

Many manufacturing companies make changes to the system, both physically and culturally, drastically to improve their competence by adopting the concept of lean manufacturing. Lean manufacturing is a waste elimination method that is very popular in both the manufacturing and service industries. Companies benefit from implementing lean manufacturing to improve quality and productivity [1]. The lean target is to eliminate waste [2]. A process that provides value added is needed to achieve perfection. Therefore, the implementation of lean manufacturing systems becomes the primary competence of every organization to remain competitive [3]. The principle of lean manufacturing eliminates waste, helping companies increase customer demand by preserving valuable resources for the future [4]. The introduction of lean principles begins by giving a closer understanding of the aspects of service and customer value inherent in them [5]. 
Lean implementation impacts the company if lean principles are inherent in the company's overall business strategy. The company integrates lean practices across operations and other business functions. As one of the critical components in financial control, management accounting practices need to be adjusted to meet the demands and objectives of lean organizations. The use of tools and techniques does not entirely determine [6] the success of the lean implementation. Still, it is also influenced by the involvement of Top Management, leadership, attitudes, and behavior of employees, resources owned, and organizational culture [7]. In small and medium industries, four main factors determine the successful implementation of lean manufacturing: leadership and management, finance, skills and expertise, and organization culture [8]. Another factor that influences the successful implementation of lean is the strategic approach to improvements [9].

The organizational culture of a company that has successfully implemented lean is a company that uses soft lean practice and hard lean practice as a whole. Soft practice implementation includes the company paying attention to employee training, small group problem solving, maintaining cooperative relationships with suppliers and customers, supporting the philosophy of continuous improvement. At the same time, the implementation of hard practice includes lean technical and analytical tools [10]. The lean implementation trend is now much better with integrating IT aspects into the company's production system known as industry 4.0. Application of Industry 4.0 can stabilize and support lean principles. Industry 4.0 offers an estimation of profits by securing lean processes with industry 4.0 applications [11]. Industry 4.0 is the three paradigms, namely smart products, smart machines, and augmented operators [12].

PT XYZ is a manufacturing company that produces polymer resins (raw material for making paint). The company adopts a make to order production system. The production process will be carried out if there are orders from customers, and the number of production volumes is adjusted to the number of requests. Production data for 2017 shows that there is a gap between production targets and production outputs. Production output that exceeds the target adds costs in product handling, storage, and reprocessing. The company experienced a production shortage of $66.67 \%$ for eight months in 2017, and the rest was overproduction (Fig. 1).

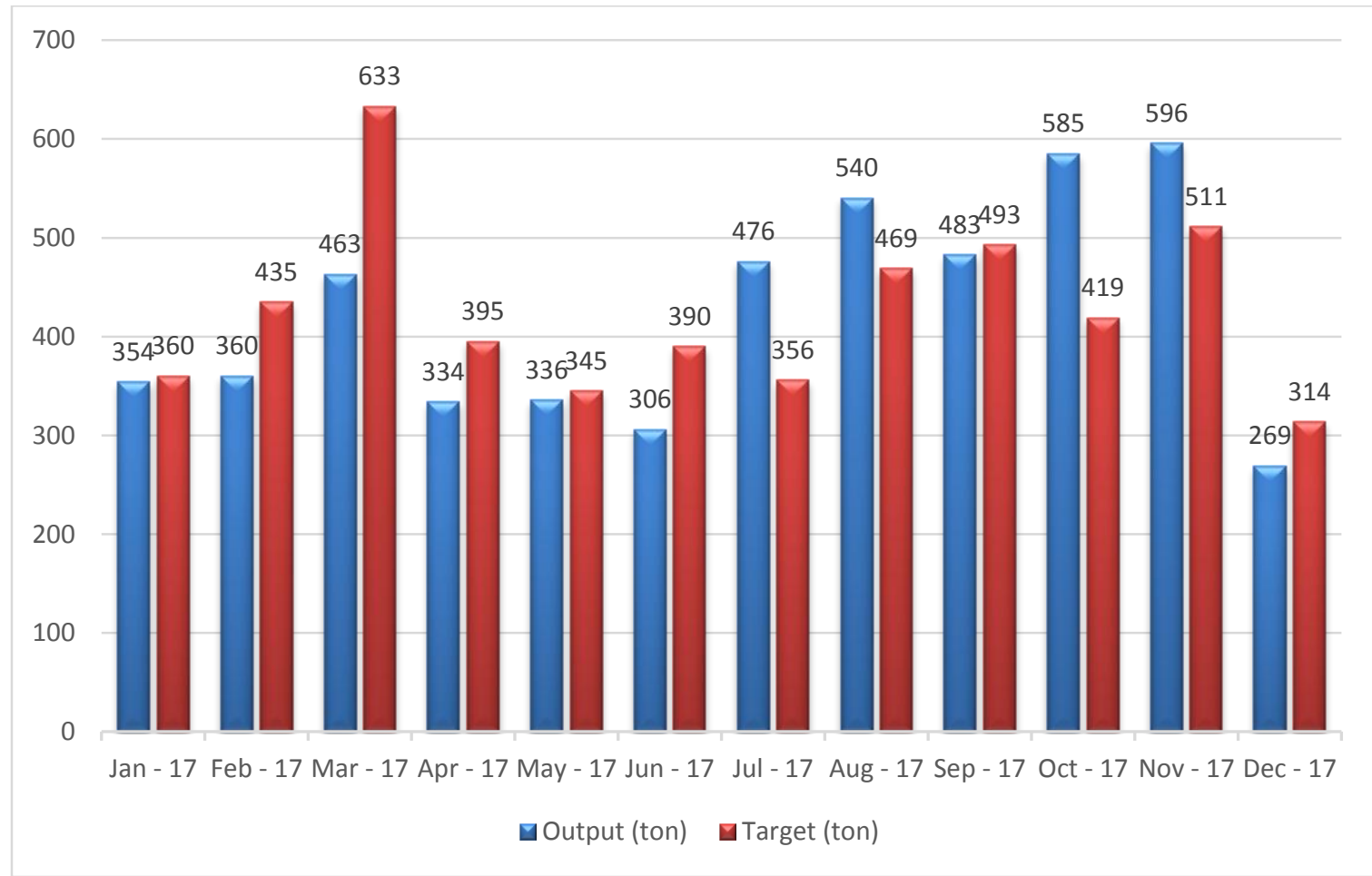

Fig. 1. The acrylic resins production output and production target 
This gap causes two main problems in the field. The first problem, with the make-to-order production system, is that customer demand tends to be sudden, so it requires speed for the production department to meet the customer's needs. Based on observations in the field, there are indications that there are several activities that cause the production process to slow down so that further analysis is needed. The second problem, the acrylic resin production process is done by maximizing the capacity of the existing reactor without considering the quantity demanded by the customer. This maximization aims to reduce production costs to be more efficient. But on the other hand, the next problem arises, namely the existence of overproduction, which results in high inventory costs.

Table 1 shows the seven wastes that came from the company's secondary data in 2017. These data reinforce the fact that there are severe problems in-process production. Lean can reduce waste that occurs in the work area and improve production line performance for the better. Implementing lean manufacturing systems becomes the main competency for each organization to remain competitive [3].

Table 1. Seven waste

\begin{tabular}{ll}
\hline Types of waste & Amount \\
\hline Transportation & 1 area \\
Inventory & 8.66 tons \\
Motion & $8 / 1$ production process \\
Delay & $1 / 1$ production process \\
Over processing & $5 \times$ in 1 year \\
Over productions & 8.66 tons \\
Defect & 1.08 tons \\
\hline
\end{tabular}

Aspects such as findings, concept definitions, and the integration of lean methods can increase employee understanding in creating and developing lean theories for use by professionals involved in lean transformations [13]. Since 2008 lean implementation has begun to eliminate waste in the form of operations and procedures that are not needed to improve customers' quality. Although many of the tools used have not been able to achieve the desired targets in its implementation, the implementation of lean has encouraged companies to increase company finances and expand market share and competitiveness [14]. Research conducted on the manufacturing industry in the Gaza Strip regarding the implementation of lean manufacturing has proven that lean manufacturing can eliminate waste in production [15].

The integration and implementation of lean elements simultaneously in the right order is needed to drive the successful implementation of lean manufacturing [3]. By integrating information and communication systems, deficiencies in conventional practice can be overcome to increase productivity and eliminate waste [16]. Some tools used in lean manufacturing are Value Stream Analysis Tools (VALSAT) and Value Stream Mapping (VSM). This tool is used to create a production flow map and information flow obtained by the company to produce products and all operational activities. All information will be mapped in a straightforward picture. The picture includes the input and output, the process of making goods, and the presence of consumers. Value Stream Mapping (VSM) is one of the fundamental lean tools used to identify opportunities for various lean techniques [17]. VSM also visualizes supply chains and value chains, which are based on the Toyota Production System, which has helped the successful implementation of lean systems [18]. The application of VSM in the automotive industry can reduce waste and labor usage, improve processes, and obtain savings [19]. The use of traditional VSM is considered sufficient to describe nonvalue added activities in simple manufacturing. However, it is more effective for complex production when using Radio Frequency Identification (RFID) and VSM-based simulations [20].

This study aims to waste in the process of knowing the process of producing acrylic resins. The results of improvements are expected to reduce lead time so that the production process is more efficient. This research is limited to analyzing the waste of the acrylic resin production process through a lean manufacturing approach by utilizing lean tools and techniques. This research has not yet involved top management and other elements that are key to the success of lean implementation in the company.

\section{RESEARCH METHODS}

This research was conducted from July to December 2017, with the study's stages, as shown in Fig. 2. Data collection was carried out directly 
and indirectly. Data needed in the analysis process are production processing time data, seven waste data, production data during 2017, and production operator daily report data. Data analysis using lean manufacturing approach.

Lean manufacturing is needed to achieve the main goal of eliminating waste. The main purpose of lean manufacturing is to eliminate waste by reducing the variability of waste sources such as suppliers, processing time, and demand [21]. Lean manufacturing is considered as a concept to reduce costs and respond to consumer needs well by many industries in the world [22], as well as the potential to increase productivity, and reduce manufacturing costs [16]. The lean approach focuses on the continuous improvement of customer value through the identification and elimination of non-value-added activities that are wasteful [23].

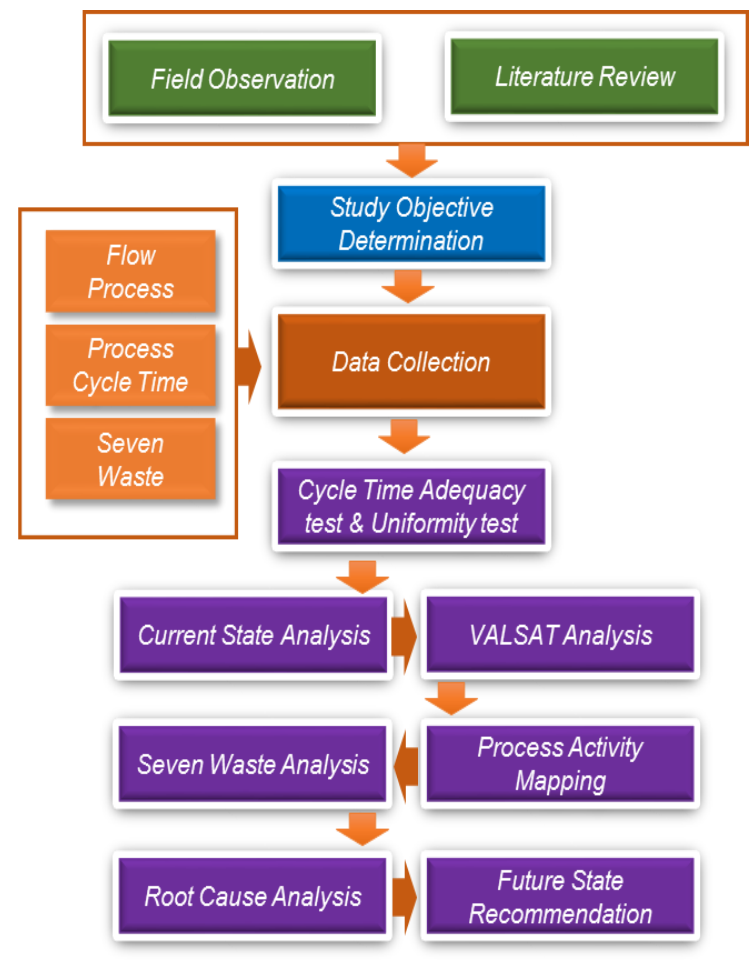

Fig. 2. Research stages

Process time data is tested for adequacy and uniformity of data before it is used for the next stage. Workflow map to be a reference in making current state mapping. In the current state mapping depicts the process flow from each work station. Test Value Stream Analysis Tools (VALSAT) from seven waste questionnaire data by weighting waste based on the table of The Seven Stream
Mapping Tools. Highest-weighting tools are the most suitable tools for further data processing. When VSM is applied in all stages of the process, then value-added and non-value-added can be analyzed and using VSM as a visual tool to help see hidden waste and its sources of waste [24].

The VALSAT results for further processing are Process Activity Mapping. Making Process Activity Mapping (PAM) is based on every work activity in the production process. Each activity is identified in detail based on the activity categories (operation, transport, inspection, delay, and storage) and the type of activity (value-added, non-value-added, necessary non-value-added). Besides that, PAM can also be analyzed based on high category waste in VALSAT. The results of processing with PAM will get delayed activity in each area.

The fishbone diagram analysis is useful to know the cause of the delay that occurs. Data obtained by interviewing employees who understand the problem [25]. The next step is to propose improvements with $5 \mathrm{~W}+1 \mathrm{H}$. With the results of the proposed increase, mapping was carried out again, namely Future State Activity Mapping and analyzed through Process Activity Mappings State. Calculation of process time efficiency is done to determine the lead time difference before and after repairs. Current State Mapping is made to map the sequence of actual processes that occur on the production floor. Future State Mapping is made to describe the design of the lean process flow after eliminating the root causes of waste through process improvement [24].

\section{RESULTS AND DISCUSSION}

The production process of acrylic resins goes through several stages, from handling raw material (RM) to packaging. Production time data is taken by sampling from each step of the process of making acrylic resins from 30 observation samples. Production time data were taken from November to December 2017 (Table 2). The data retrieval results are then tested for adequacy and uniformity of the data to ensure the feasibility of the data before further processing. From 30 samples of acrylic resins production process time, the result of cycle time or average production process time is obtained.

The average time is a reference in making flow process charts and current state activity 
mapping that aims to distinguish activities that have added value to non-value-added. Analysis of the current state activity mapping (Fig. 2), shows a lead time of 1298 minutes is obtained with a value-added time of 1016 minutes, non-valueadded, and necessary non-value-added time of 282 minutes. Non-value-added activities occur in the process of loading raw material and the dilution process until the end. The computerized polymerization process can minimize non-valueadded activities. Elimination of activities that have no added value is the main goal in implementing lean manufacturing. Activities that do not have added value, in the long run, will result in the production system being not affective and causing high costs.

Table 2. Processing time data in november to december 2017

\begin{tabular}{|c|c|c|c|c|c|c|c|c|c|c|c|}
\hline \multirow[b]{2}{*}{ Observation } & \multicolumn{11}{|c|}{ Activities (minutes) } \\
\hline & $\begin{array}{c}\text { Raw } \\
\text { material } \\
\text { preparation }\end{array}$ & $\begin{array}{c}\text { Raw } \\
\text { material } \\
\text { inspection }\end{array}$ & $\begin{array}{c}\text { Input raw } \\
\text { material } \\
\text { A }\end{array}$ & Heating & $\begin{array}{l}\text { Mix } \\
\text { mon \& } \\
\text { catalyst }\end{array}$ & Droping & Holding & Cooling & $\begin{array}{l}\text { Pompa } \\
\text { Solvent }\end{array}$ & $\begin{array}{l}\text { Finished } \\
\text { goods } \\
\text { inspection }\end{array}$ & Druming \\
\hline 1 & 160 & 50 & 187 & 90 & 20 & 300 & 165 & 60 & 30 & 180 & 70 \\
\hline 2 & 160 & 55 & 185 & 95 & 25 & 300 & 135 & 75 & 30 & 170 & 80 \\
\hline 3 & 165 & 55 & 187 & 100 & 25 & 300 & 150 & 70 & 20 & 175 & 75 \\
\hline 4 & 160 & 40 & 190 & 98 & 25 & 300 & 165 & 60 & 25 & 185 & 78 \\
\hline 5 & 155 & 54 & 190 & 97 & 20 & 300 & 135 & 60 & 30 & 187 & 85 \\
\hline 6 & 155 & 58 & 187 & 98 & 20 & 300 & 150 & 75 & 20 & 183 & 78 \\
\hline 7 & 158 & 50 & 189 & 88 & 25 & 300 & 120 & 70 & 25 & 170 & 78 \\
\hline 8 & 150 & 55 & 185 & 85 & 25 & 300 & 135 & 60 & 30 & 177 & 84 \\
\hline 9 & 160 & 55 & 195 & 95 & 20 & 300 & 150 & 55 & 25 & 187 & 80 \\
\hline 10 & 165 & 50 & 190 & 100 & 25 & 300 & 135 & 65 & 30 & 175 & 75 \\
\hline 11 & 155 & 54 & 186 & 98 & 25 & 300 & 150 & 75 & 20 & 185 & 78 \\
\hline 12 & 160 & 58 & 187 & 97 & 20 & 300 & 120 & 70 & 25 & 187 & 85 \\
\hline 13 & 155 & 40 & 189 & 98 & 30 & 300 & 135 & 60 & 30 & 183 & 78 \\
\hline 14 & 160 & 54 & 190 & 88 & 30 & 300 & 135 & 55 & 30 & 170 & 80 \\
\hline 15 & 158 & 58 & 190 & 98 & 25 & 300 & 135 & 65 & 25 & 177 & 84 \\
\hline 16 & 158 & 50 & 187 & 88 & 25 & 300 & 135 & 75 & 25 & 185 & 78 \\
\hline 17 & 160 & 55 & 188 & 85 & 20 & 300 & 135 & 70 & 30 & 183 & 80 \\
\hline 18 & 165 & 50 & 186 & 95 & 25 & 300 & 150 & 60 & 25 & 170 & 84 \\
\hline 19 & 160 & 54 & 190 & 100 & 25 & 300 & 120 & 55 & 20 & 177 & 80 \\
\hline 20 & 155 & 58 & 189 & 98 & 20 & 300 & 165 & 65 & 30 & 187 & 75 \\
\hline 21 & 160 & 50 & 185 & 97 & 25 & 300 & 135 & 60 & 25 & 175 & 78 \\
\hline 22 & 160 & 55 & 190 & 85 & 20 & 300 & 135 & 55 & 30 & 185 & 85 \\
\hline 23 & 158 & 55 & 180 & 95 & 20 & 300 & 150 & 65 & 25 & 177 & 78 \\
\hline 24 & 160 & 50 & 190 & 100 & 20 & 300 & 120 & 75 & 25 & 183 & 76 \\
\hline 25 & 160 & 54 & 187 & 98 & 25 & 300 & 150 & 70 & 30 & 170 & 84 \\
\hline 26 & 155 & 58 & 196 & 98 & 20 & 300 & 120 & 60 & 30 & 177 & 78 \\
\hline 27 & 155 & 50 & 185 & 97 & 20 & 300 & 150 & 60 & 30 & 187 & 78 \\
\hline 28 & 158 & 55 & 195 & 85 & 25 & 300 & 120 & 55 & 25 & 175 & 84 \\
\hline 29 & 155 & 50 & 185 & 95 & 20 & 300 & 120 & 65 & 30 & 185 & 80 \\
\hline 30 & 160 & 54 & 195 & 100 & 20 & 300 & 150 & 60 & 25 & 177 & 79 \\
\hline$\sum$ & 4755 & 1584 & 5655 & 2841 & 690 & 9000 & 4170 & 1925 & 800 & 5384 & 2385 \\
\hline $\bar{X}$ & 158.5 & 52.8 & 188.5 & 94.7 & 23.0 & 300.0 & 139.0 & 64.2 & 26.7 & 179.5 & 79.5 \\
\hline
\end{tabular}




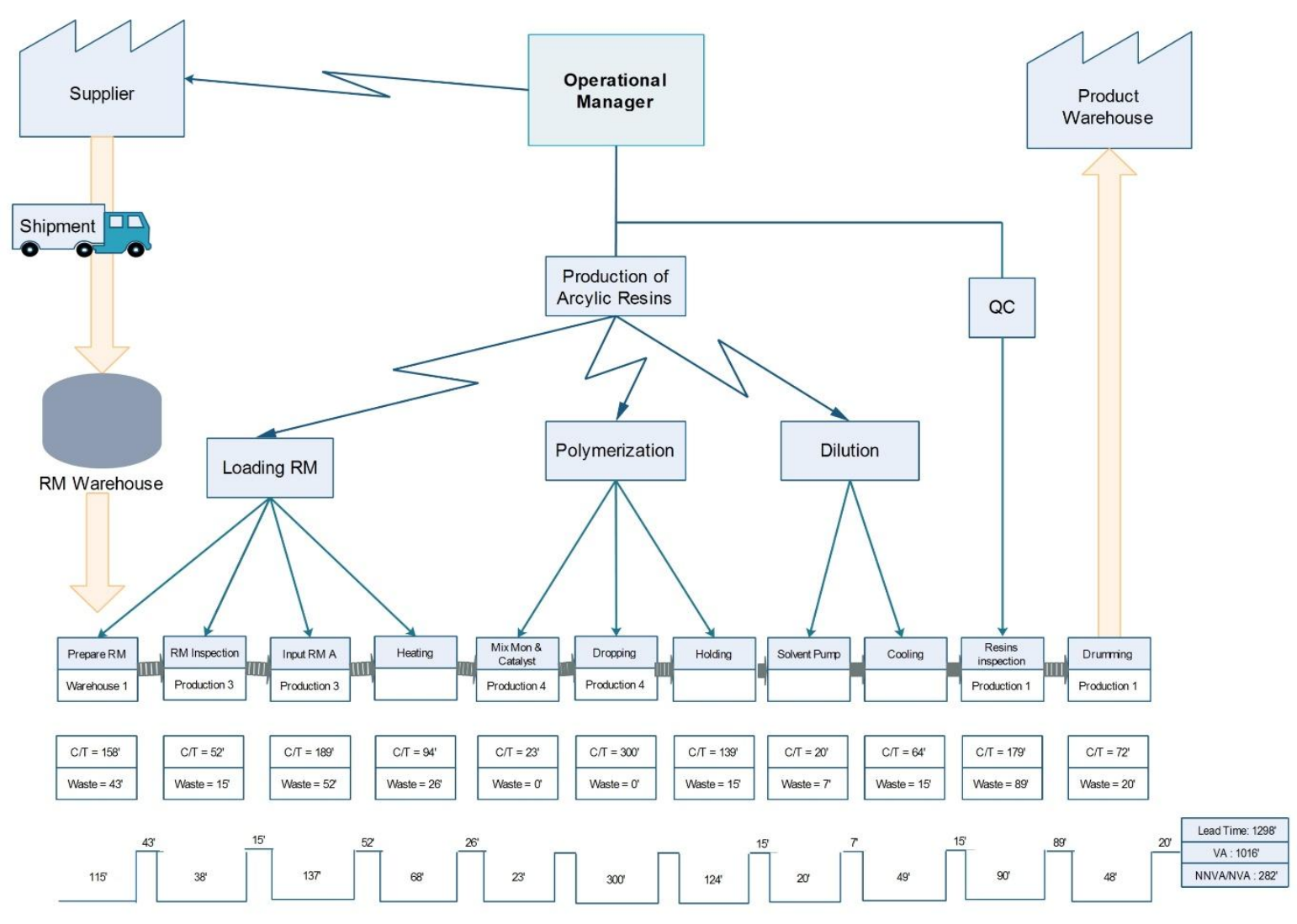

Fig. 3. Current state activity mapping

Seven waste data is taken based on the history of the production process in 2017. Besides, using data supporting the results of the distribution of questionnaires to determine the percentage of each type of waste. The questionnaire uses a likert scale of 1 to 5, with very low, low, medium, high, and very high evaluation criteria (Table 3 ). The next analysis process is the calculation of Value Stream
Analysis Tools (VALSAT). Calculation of VALSAT by multiplying the weight of waste obtained from the results of the seven waste questionnaire (Table 3) multiplied by the standard VALSAT correlation value, namely high correlation score 9, medium correlation score 3, and low correlation score 1 (Table 4).

Table 3. The seven waste questionnaire

\begin{tabular}{llccccccc}
\hline \multirow{2}{*}{ No } & Category respondent & $\begin{array}{c}\text { Over } \\
\text { production }\end{array}$ & Delay & Transportation & $\begin{array}{c}\text { Inappropriate } \\
\text { processing }\end{array}$ & $\begin{array}{c}\text { Unnecessary } \\
\text { inventory }\end{array}$ & Defect & Motion \\
\hline 1 & Production manager (FB) & 2 & 3 & 1 & 1 & 2 & 2 & 1 \\
2 & Production supervisor (HF) & 2 & 4 & 1 & 1 & 2 & 1 & 2 \\
3 & Leader 1 (CB) & 3 & 4 & 2 & 2 & 3 & 2 & 1 \\
4 & Leader 2 (WI) & 2 & 3 & 2 & 2 & 2 & 2 & 1 \\
5 & Leader 3 (KA) & 2 & 4 & 2 & 2 & 2 & 2 & 2 \\
6 & Leader 4 (NS) & 3 & 3 & 1 & 2 & 3 & 2 & 2 \\
7 & Operator (PA) & 1 & 2 & 1 & 1 & 1 & 1 & 1 \\
8 & Engineer (BS) & 1 & 4 & 2 & 2 & 1 & 2 & 2 \\
\hline & Total & 16 & 27 & 12 & 13 & 16 & 14 & 12 \\
\hline
\end{tabular}


Table 4. VALSAT calculation

\begin{tabular}{|c|c|c|c|c|c|c|c|}
\hline $\begin{array}{c}\text { Wastes } \\
\text { structure }\end{array}$ & $\begin{array}{c}\text { Process } \\
\text { activity } \\
\text { mapping }\end{array}$ & $\begin{array}{c}\text { Supply } \\
\text { chain } \\
\text { response } \\
\text { matrix }\end{array}$ & $\begin{array}{c}\text { Prod } \\
\text { variety } \\
\text { funnel }\end{array}$ & $\begin{array}{l}\text { Quality } \\
\text { filter } \\
\text { mapping }\end{array}$ & $\begin{array}{l}\text { Demand } \\
\text { application } \\
\text { mapping }\end{array}$ & $\begin{array}{c}\text { Decision } \\
\text { point } \\
\text { analysis }\end{array}$ & $\begin{array}{c}\text { Physical } \\
\text { structure } \\
\text { (a) volume } \\
\text { (b) value }\end{array}$ \\
\hline $\begin{array}{c}\text { Over } \\
\text { production }\end{array}$ & 0.15 & 0.45 & - & 0.15 & 0.45 & 0.45 & - \\
\hline Delay & 2.25 & 2.25 & 0.25 & - & 0.75 & 0.75 & 0.25 \\
\hline Transport & 0.99 & - & - & - & - & - & - \\
\hline $\begin{array}{c}\text { Inappropriate } \\
\text { processing }\end{array}$ & 1.08 & - & 0.36 & 0.12 & - & 0.12 & - \\
\hline $\begin{array}{l}\text { Unnecessary } \\
\text { inventory }\end{array}$ & 0.45 & 1.35 & 0.45 & - & 1.35 & 0.45 & 0.15 \\
\hline $\begin{array}{l}\text { Unnecessary } \\
\text { motion }\end{array}$ & 0.33 & 0.11 & - & - & - & - & - \\
\hline Defect & 0.13 & - & - & - & - & - & - \\
\hline Total & 5.38 & 4.16 & 1.06 & 0.27 & 2.55 & 1.77 & 0.4 \\
\hline
\end{tabular}

Based on the results of VALSAT processing, the highest weighting tools are Process Activity Mapping (PAM) with a score of 5.38 (Table 4). PAM is the most suitable tool for further data processing [18]. Making Process Activity Mapping (PAM) is based on every work activity in the production process. Each activity is identified in detail based on the category of activities (operation, inspection, transport, delay, storage) and type of activity (value-added, nonvalue-added, necessary non-value-added).

Table 5. Production processing times

\begin{tabular}{llccc}
\hline No & \multicolumn{1}{c}{ Activities } & Qty & $\begin{array}{c}\text { Time } \\
\text { (minutes) }\end{array}$ & $\begin{array}{c}\text { Percentage } \\
(\boldsymbol{\%})\end{array}$ \\
\hline 1 & Operation & 8 & 721 & 55.55 \\
2 & Transportation & 2 & 130 & 10.02 \\
3 & Inspection & 4 & 180 & 13.87 \\
4 & Storage & 1 & 52 & 4.01 \\
5 & Delay & 4 & 215 & 16.56 \\
\hline \multicolumn{2}{r}{ Total } & 1298 & 100 \\
\hline
\end{tabular}

Table 6. Type of activity

\begin{tabular}{lc}
\hline \multicolumn{1}{c}{ Activities } & $\begin{array}{c}\text { Time of current } \\
\text { state (minutes) }\end{array}$ \\
\hline Value added (VA) & 888 \\
Non value added (NVA) & 162 \\
$\begin{array}{l}\text { Necessary non value added } \\
\text { (NNVA) }\end{array}$ & 248 \\
\hline \multicolumn{1}{c}{ Lead time } & 1298 \\
\hline
\end{tabular}

The percentage of activities with PAM shows activity delay of $16.56 \%$ and transportation $10.02 \%$ (Table 5) with non-value-added for 162 minutes (Table 6). Similar results as a study conducted by Jaffar et al., [26] in one of the automotive vendor companies in Malaysia found that three primary sources of waste cause engine downtime, namely waiting, transportation and movement with a value of $28 \%, 25$ respectively $\%$ and $12 \%$. The types of activities that include Value Added are moving raw material (RM) from the warehouse to production, heating, mix monomers and catalysts, dropping, holding, cooling, solvent pumping, and drumming. While the activities included in Non Value Added are waiting for all RM to be collected, preparing RM input, waiting for temperature process, changing filters, waiting for drumming to finish. Things that include necessary non-value-added activities are RM Inspection, double-checking reactor conditions, preparing monomers and catalysts, transferring resins to thinning thank, checking filter conditions, and product inspection.

These activities are found in 3 areas, namely $60.93 \%$ thining tanks, $26.98 \%$ reactors, and $12.09 \%$ monomer tanks (Table 7). The highest delay is in the thining tank area. According to management's recommendation, problem-solving will be done in 2 areas with the highest delay, namely the Thinning Tank area and the Reactor area.

Table 7. Delay area in resins production

\begin{tabular}{ccc}
\hline Delay area & $\begin{array}{c}\text { Time } \\
\text { (minutes) }\end{array}$ & $\begin{array}{c}\text { Percentage } \\
(\mathbf{\%})\end{array}$ \\
\hline Reactor & 58 & 26.98 \\
Monomer tank & 26 & 12.09 \\
Thinning tank & 131 & 60.93 \\
\hline Total & 215 & $100 \%$ \\
\hline
\end{tabular}


Analysis of the root causes of the problem of delay in the Thinning Tank area and the Reactor area conducted brainstorming involving several employees who understand the problem include production managers, production supervisors, leaders, senior operators, and junior operators. The results of the brainstorming are then outlined in a fishbone diagram. The results of the analysis using a fishbone diagram obtained the root cause of the problem of delay in the Thinning Tank area, and the Reactor area are as follows:

1. Thank thinning area: The engine filter is lacking maintenance causing frequent removal of filter pairs, the filter size is too tight, and viscosity is high resins. There is no SOP review on the drumming process so that it inhibits the drumming process, and the temperature of the resins is too low, resulting in viscosity too high.

2. Reactor area: The freight elevator to supply the $\mathrm{RM}$ from the warehouse to the production is too small so that it inhibits the delivery of material, the distance of the RM warehouse to the reactor is too far, the operator is not given enough training related to the process in the reactor area, plus the air circulation is not optimal so that the working environment is not comfortable.

$5 \mathrm{~W}+1 \mathrm{H}$ is a tool used to reduce lead time in the acrylic resins production process. The corrective steps that can be done are routine maintenance of the engine filter, adjusting the filter density to the type of resin, and the thickness of the resin. Besides by evaluating SOP drumming regularly. Conducting drumming at higher temperatures but still below the boiling point of the solvent used. Conduct routine training on handling RM and production processes, adding forklifts and moving equipment to prepare raw materials. The arrangement of raw material is more optimized so that the elevator can load more goods. Another improvement that can be done is to add a blower or air conditioner (AC) in the area.

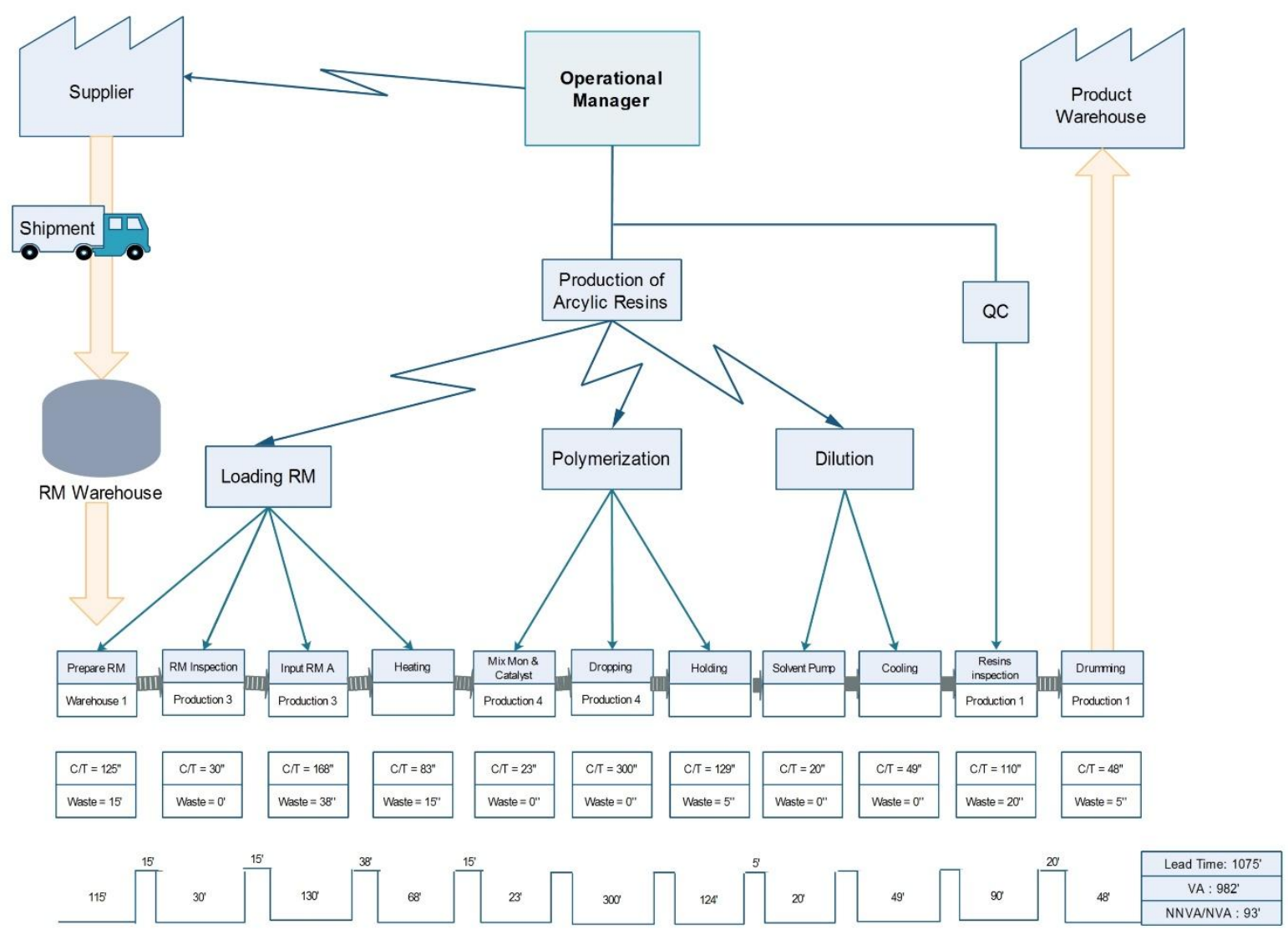

Fig. 4. Future state activity mapping 
Process activity mapping and future state activity mapping analysis are used to evaluate the improvements that have been made (Fig. 4). Based on the results of improvements, there was a significant decrease in processing time for each activity. The most significant reduction in time is the non-value-added activity of 117 minutes compared to the previous activity. Similarly, the necessary non-value-added activity obtained a decrease in time of 80 minutes. Time efficiency in NVA activities is obtained because there are activities that can be eliminated and reduced based on proposed improvements (Table 8).

Table 8. Comparison of lead time

\begin{tabular}{lccc}
\hline Activities & $\begin{array}{c}\text { Before } \\
\text { (minutes) }\end{array}$ & $\begin{array}{c}\text { After } \\
\text { (minutes) }\end{array}$ & $\begin{array}{c}\text { Differences } \\
\text { (minutes) }\end{array}$ \\
\hline Value added & 888 & 872 & 16 \\
$\begin{array}{l}\text { Non value added } \\
\text { Necessary non }\end{array}$ & 162 & 35 & 117 \\
value added & 248 & 168 & 80 \\
\hline Lead time & 1298 & 1075 & 213 \\
\hline
\end{tabular}

The application of lean manufacturing in the acrylic resins production process of PT. XYZ can increase the efficiency of production time by $17.18 \%$, which means the output ratio will increase by around $17.18 \%$ in one production process. Similar results as a study conducted by Dickson et.al, [27] where Lean was able to increase patient satisfaction in a hospital emergency department by $9.23 \%$, through simplification of procedures, simplification of processes and places.

\section{CONCLUSION}

The lead time of the acrylic resins production process before repairing was 1298 minutes, and after improvement it to 1075 minutes, there was an increase in the efficiency of the acrylic resins production process time of $17.18 \%$. The implications of research on company management are the growing awareness of management to continue to make improvements continuously both in the field of process governance and in the field of human resource development. The efficiency of the acrylic resins production process by continually improving production processes and periodic machine maintenance. The weakness of this research is that there is no integration of IT aspects at the production, planning, customer, and supplier levels or known as lean production industry 4.0.

\section{REFERENCES}

[1] A. N. A. Wahab, M. Mukhtar, and R. Sulaiman, "A Conceptual Model of Lean Manufacturing Dimensions," Procedia Technol., vol. 11, pp. 1292-1298, 2013, doi: 10.1016/j.protcy.2013.12.327.

[2] R. Čiarnienè and M. Vienažindienè, "Lean Manufacturing: Theory And Practice," Econ. Manag., vol. 17, no. 2, pp. 726-732, Aug. 2012, doi: 10.5755/j01.em.17.2.2205.

[3] R. Sundar, A. N. Balaji, and R. M. S. Kumar, "A Review on Lean Manufacturing Implementation Techniques," Procedia Eng., vol. 97, pp. 1875-1885, 2014, doi: 10.1016/j.proeng.2014.12.341.

[4] G. Miller, J. Pawloski, and C. R. Standridge, "A case study of lean, sustainable manufacturing," J. Ind. Eng. Manag., vol. 3, no. 1, pp. 11-32, 2010, doi: 10.3926/jiem.v3n1.p11-32.

[5] E. Andrés-López, I. González-Requena, and A. Sanz-Lobera, "Lean Service: Reassessment of Lean Manufacturing for Service Activities," Procedia Eng., vol. 132, pp. 23-30, 2015, doi: 10.1016/j.proeng.2015.12.463.

[6] R. R. Fullerton, F. A. Kennedy, and S. K. Widener, "Lean manufacturing and firm performance: The incremental contribution of lean management accounting practices," J. Oper. Manag., vol. 32, no. 7-8, pp. 414-428, Nov. 2014, doi: 10.1016/j.jom.2014.09.002.

[7] J. R. Jadhav, S. S. Mantha, and S. B. Rane, "Exploring barriers in lean implementation," Int. J. Lean Six Sigma, vol. 5, no. 2, pp. 122-148, May 2014, doi: 10.1108/IJLSS-12-2012-0014.

[8] P. Achanga, E. Shehab, R. Roy, and G. Nelder, "Critical success factors for lean implementation within SMEs," J. Manuf. Technol. Manag., vol. 17, no. 4, pp. 460471, Jun. 2006, doi: $10.1108 / 17410380610662889$.

[9] M. AlManei, K. Salonitis, and Y. Xu, 
"Lean Implementation Frameworks: The Challenges for SMEs," Procedia CIRP, vol. 63, pp. 750-755, 2017, doi: 10.1016/j.procir.2017.03.170.

[10] T. Bortolotti, S. Boscari, and P. Danese, "Successful lean implementation: Organizational culture and soft lean practices," Int. J. Prod. Econ., vol. 160, pp. 182-201, Feb. 2015, doi: 10.1016/j.ijpe.2014.10.013.

[11] T. Wagner, C. Herrmann, and S. Thiede, "Industry 4.0 Impacts on Lean Production Systems," Procedia CIRP, vol. 63, pp. 125-131, 2017, doi: 10.1016/j.procir.2017.02.041.

[12] B. Mrugalska and M. K. Wyrwicka, "Towards Lean Production in Industry 4.0," Procedia Eng., vol. 182, pp. 466473, 2017, doi: 10.1016/j.proeng.2017.03.135.

[13] K. B. Stone, "Four decades of lean: a systematic literature review," Int. J. Lean Six Sigma, vol. 3, no. 2, pp. 112-132, Jun. 2012, doi: $10.1108 / 20401461211243702$.

[14] M. K. Wyrwicka and B. Mrugalska, "Mirages of Lean Manufacturing in Practice," Procedia Eng., vol. 182, pp. 780-785, 2017, doi: 10.1016/j.proeng.2017.03.200.

[15] K. Elnamrouty and M. S. Abushaaban, "Seven wastes elimination targeted by lean manufacturing case study "gaza strip manufacturing firms"," Seven wastes Elimin. Target. by lean Manuf. case study "gaza strip Manuf. firms", vol. 1, no. 2, 2013, available: http://www.sciencepublishinggroup.com/j ournal/paperinfo.aspx?journalid=173\&doi $=10.11648 / \mathrm{j} . \mathrm{ijefm} \cdot 20130102.12$.

[16] A. Sanders, C. Elangeswaran, and J. Wulfsberg, "Industry 4.0 implies lean manufacturing: Research activities in industry 4.0 function as enablers for lean manufacturing," J. Ind. Eng. Manag., vol. 9, no. 3, p. 811, Sep. 2016, doi: 10.3926/jiem.1940.

[17] A. R. Rahani and M. Al-Ashraf, "Production Flow Analysis through Value Stream Mapping: A Lean Manufacturing
Process Case Study," Procedia Eng., vol. 41, pp. 1727-1734, 2012, doi: 10.1016/j.proeng.2012.07.375.

[18] U. K. Teichgräber and M. de Bucourt, "Applying value stream mapping techniques to eliminate non-value-added waste for the procurement of endovascular stents," Eur. J. Radiol., vol. 81, no. 1, pp. e47-e52, Jan. 2012, doi: 10.1016/j.ejrad.2010.12.045.

[19] A. P. Lacerda, A. R. Xambre, and H. M. Alvelos, "Applying Value Stream Mapping to eliminate waste: a case study of an original equipment manufacturer for the automotive industry," Int. J. Prod. Res., vol. 54, no. 6, pp. 1708-1720, Mar. 2016, doi: 10.1080/00207543.2015.1055349.

[20] B. Singh, S. K. Garg, S. K. Sharma, and C. Grewal, "Lean implementation and its benefits to production industry," Int. J. Lean Six Sigma, vol. 1, no. 2, pp. 157-168, May 2010, doi: 10.1108/20401461011049520.

[21] R. Shah and P. T. Ward, "Defining and developing measures of lean production," J. Oper. Manag., vol. 25, no. 4, pp. 785805, Jun. 2007, doi: 10.1016/j.jom.2007.01.019.

[22] J. Bhamu and K. Singh Sangwan, "Lean manufacturing: literature review and research issues," Int. J. Oper. Prod. Manag., vol. 34, no. 7, pp. 876-940, Jul. 2014, doi: 10.1108/IJOPM-08-2012-0315.

[23] A. Mousa, "Lean, Six sigma and Lean six sigma overview," Int. J. Sci. Eng. Res., vol. 4, no. 5, pp. 1137-1153, 2013, available: https://www.ijser.org/researchpaper/Leansix-sigma-and-lean-six-sigmaOverview.pdf.

[24] S. Mostafa and J. Dumrak, "Waste Elimination for Manufacturing Sustainability," Procedia Manuf., vol. 2, pp. 11-16, 2015, doi: 10.1016/j.promfg.2015.07.003.

[25] J. P. Womack and D. T. Jones, "Lean Thinking-Banish Waste and Create Wealth in your Corporation," in Journal of the Operational Research Society, vol. 48, 
no. 11, Taylor \& Francis, 1997, pp. $1148-$ 1148, doi: 10.1057/palgrave.jors.2600967.

[26] A. Jaffar, S. Kasolang, Z. A. Ghaffar, N. S. Mohamad, and M. K. F. Mohamad, "Management of Seven Wastes: A Case Study in an Automotive Vendor," $J$. Teknol., vol. 76, no. 6, 2015, available: https://jurnalteknologi.utm.my/index.php/j urnalteknologi/article/view/5668.

[27] E. W. Dickson, S. Singh, D. S. Cheung, C. C. Wyatt, and A. S. Nugent, "Application of Lean Manufacturing Techniques in the Emergency Department," J. Emerg. Med., vol. 37, no. 2, pp. 177-182, Aug. 2009, doi: 10.1016/j.jemermed.2007.11.108. 